Dr hab. Ewa Czech, prof. UwB*

Mgr Martyna Kropiewnicka**

\title{
MIĘDZYNARODOWA WSPÓŁPRACA POLSKIEGO SAMORZĄDU TERYTORIALNEGO SZCZEBLA POWIATOWEGO W ZAKRESIE OCHRONY ŚRODOWISKA REALIZOWANEJ W ZGODZIE ZE ZRÓWNOWAŻONYM ROZWOJEM
}

\section{Uwagi wstępne}

Rzeczpospolita Polska z coraz większym zaangażowaniem uczestniczy na poziomie międzynarodowym we współpracy prowadzonej na rzecz ochrony środowiska. Przyczyniło się do tego z pewnością członkostwo Polski w Unii Europejskiej, Radzie Europy czy innych organizacjach międzynarodowych, np. Stowarzyszeniu Europejskich Regionów Granicznych oraz jej strategiczne położenie, dzięki któremu jest ona niejako łącznikiem pomiędzy zachodnią a wschodnią częścią Europy.

$\mathrm{Z}$ początkiem lat 90 -tych Polska zaczęła współpracę międzynarodową na poziomie samorządów terytorialnych, co stanowiło zupełnie nowy wymiar współdziałania i było odzwierciedleniem przemian ustrojowych. Okazało się, że istnieje wyraźna potrzeba integracji nie tylko na szczeblu państwowym, ale również lokalnym, co było następstwem postępującej decentralizacji państw. ${ }^{283} \mathrm{Z}$ racji tego, iż środowisko traktowane jest jako dobro o charakterze powszechnym i niepodzielnym, naturalnym stało się rozpatrywanie ochrony środowiska w kontekście współpracy podmiotów lokalnych na szczeblu międzynarodowym, zwłaszcza w formie współpracy transgranicznej. ${ }^{284}$

\footnotetext{
* Kierownik Zakładu Prawa Ochrony Środowiska i Nauki Administracji Publicznej Wydziału Prawa UwB

** Doktorantka w Zakładzie Prawa Ochrony Środowiska i Nauki Administracji Publicznej Wydziału Prawa UwB

283 E. Grzyb, Formy współpracy międzynarodowej jednostek samorządu terytorialnego na przykładzie miasta Chełm, Warszawa 2010, s. 3.

284 W. Jastrzębska, Rola euroregionów i współpracy transgranicznej w procesie integracji europejskiej, [w:] Spójność społeczno-ekonomiczna a modernizacja regionów transgranicznych, pod red. M.G. Woźniak, Rzeszów 2008, s. 97.
} 
Brzmienie zrównoważonego rozwoju funkcjonujące tak w prawie międzynarodowym jak i krajowym powoduje, że nie może zostać uznane za bezsporne jego utożsamianie z ochroną środowiska. Należy w zrównoważonym rozwoju widzieć m.in. taki wyznacznik działań służących ochronie środowiska, który wyłącza ochronę totalną tej wartości prawnej, tj. prowadzoną kosztem wszelkich innych wartości chronionych prawnie, które mogą pozostawać w kolizji z ochroną środowiska. Ustawodawca polski dopuszcza ograniczenie konstytucyjnych praw i wolności z uwagi na ochronę środowiska. Możliwość ograniczenia tych praw i wolności obwarowana jest jednak koniecznością spełnienia warunków określonych w treści art. 31 ust. 3 Konstytucji Rzeczpospolitej Polskiej z 1997 r. ${ }^{285}$ Jednocześnie należy podkreślić, że niemożliwe jest do obrony stanowisko postulujące rozdzielność sfer zrównoważonego rozwoju i ochrony elementów przyrodniczych.

Przyjmując takie usytuowanie względem siebie realizacji ochrony środowiska i realizacji zrównoważonego rozwoju, za zasadne należy uznać poddanie rozważaniom problematyki możliwości współpracy międzynarodowej polskiego samorządu szczebla powiatowego na rzecz ochrony środowiska w kontekście konieczności realizacji tego zadania w zgodzie z zasadą zrównoważonego rozwoju.

\section{Problematyka zrównoważonego rozwoju w kontekście międzynarodowej współpracy polskiego samorządu terytorialnego szczebla powiatowego}

Koncepcja zrównoważonego rozwoju została stworzona w wyniku obrad Konferencji ONZ „Środowisko i Rozwój”, która odbyła się w Rio de Janeiro w 1992 r. Rezultatem zebrania delegacji państw oraz ponad stu organizacji pozarządowych była Deklaracja z Rio w Sprawie Środowiska i Rozwoju oraz Globalny Program Działań zwany Agendą 21. ${ }^{286} \mathrm{~W}$ tekście Deklaracji określone zostało dwadzieścia siedem zasad odnoszących się do zrównoważonego rozwoju, m.in. prawo człowieka do zdrowego i twórczego życia w harmonii z przyrodą czy odpowiedzialność państw przed obecnymi i przyszłymi pokoleniami za zapewnienie, że ich działalność nie spowoduje zniszczenia środowiska. Kluczową zasadą na gruncie omawianej tematyki jest dwudziesta druga zasada, która stanowi, iż „Ludność tubylcza i ich wspólnoty, a także inne wspólnoty lokalne odgrywaja znaczna rolę $w$ zarzadzaniu środowiskiem i rozwoju, ze względu na ich wiedzę i tradycję (...) Państwa powinny umożliwić im efektywny udział w osiaganiu zrównoważonego rozwoju. " Sygnatariusze Deklaracji z Rio kierują więc w stosunku do organów państwowych powinność włączenia do współpracy międzynarodowej w zakresie ochrony środowiska, reali-

286 M. Micińska, Udział społeczeństwa w ochronie środowiska, Toruń 2011, s. 34. 
zowanej w zgodzie ze zrównoważonym rozwojem, również samych obywateli, ich zrzeszeń oraz jednostki samorządu terytorialnego, jako że zgodnie z zasadą pomocniczości, zadania które mogą być skutecznie zrealizowane przez szczebel niższy lub same jednostki działające w ramach społeczeństwa, powinny być przez nie wykonywane. ${ }^{287}$ Ochrona środowiska jest dziedziną życia, która w sposób szczególny związana jest z bytem poszczególnych społeczności lokalnych i często mają one większą świadomość istniejących na danym terytorium problemów czy potrzeb niż władze państwowe. Ten kierunek działań został wyrażony podczas kolejnego Szczytu Ziemi w Rio de Janeiro zwanego Rio +20, który odbył się w dniach 20-22 czerwca 2012 r. i był swego rodzaju jubileuszowym zjazdem, zorganizowanym na 20-lecie wdrażania koncepcji przyjętych podczas pierwszego Szczytu Ziemi w Rio w 1992 r. oraz 10-lecie Światowego Szczytu Zrównoważonego Rozwoju (WSSD) w Johannesburgu. ${ }^{288}$ Podczas Rio +20 odbyła się Konferencja Narodów Zjednoczonych nt. zrównoważonego rozwoju. Miała ona na celu ożywienie politycznego zainteresowania zrównoważonym rozwojem, dokonanie oceny postępu, jaki miał miejsce na przestrzeni ostatnich 20 lat i rozpoznanie luk, które pozostały do zapełnienia $\mathrm{w}$ implementacji zaleceń poprzednich konferencji, w tym przede wszystkim Szczytów Ziemi, ponadto wskazanie nowych pojawiających sie wyzwań we wzajemnych oddziaływaniach człowieka i środowiska. Podobnie jak 20 lat wcześniej myślą przewodnią Rio+20 było zaangażowanie wszystkich sektorów życia społecznego i wszystkich ,głównych grup”, zgodnie z określeniem zawartym w programie Agenda 21, w tym m.in. społeczności lokalnych. ${ }^{289}$ Jednym z elementów Konferencji podczas Rio +20 było stworzenie koncepcji tzw. zrównoważonych miast. Miasta uznane zostały za centra rozwoju społecznego i ekonomicznego, jednak stwierdzono, iż warunkiem postępu na terenach zurbanizowanych jest ograniczenie nadmiernego wykorzystywania terenów i niekontrolowanej eksploatacji zasobów naturalnych. W tym kontekście przed lokalnymi społecznościami stoi wyzwanie współtworzenia tzw. „zielonej gospodarki”, m.in. poprzez poprawę systemów transportu, budownictwa, energetyki, wodociągów oraz usuwania nieczystości. ${ }^{290}$

W kontekście przeprowadzanych rozważań konieczne jest także podkreślenie znaczącej roli zasady wyrażającej się w tym, iż dla osiągnięcia zrównoważonego rozwoju niezbędne jest, aby ochrona środowiska stanowiła nierozłączną część procesów rozwojowych i nie była rozpatrywana oddzielnie od nich (zasada czwarta Deklaracji z Rio). Oznacza to m.in. swoistą koherencję i integrację aspektów eko-

\footnotetext{
287 J. Zimmerman, Prawo administracyjne, Warszawa 2010, s. 89.

288 J. Jonker, M. Krukowska, Transformacja w kierunku zrównoważonego rozwoju. Siedem zasad koniecznych do wprowadzenia „zielonej gospodarki” - wkład do przygotowań do Rio +20 (Konferencji Organizacji Narodów Zjednoczonych na rzecz Zrównoważonego Rozwoju) w 2012 roku, „Management and Business Administration. Central Europe" 2012, Nr 4, s. 92-106.

289 Tryb dostępu: www.unesco.pl/rio-20, dnia 14.12.2012 r.

290 Tryb dostępu: http://www.unic.un.org.pl/rio20/miasta.php, dnia 14.12.2012 r.
} 
logicznych, ekonomicznych i społecznych w procesie rozwoju państw. ${ }^{291}$ Należy podkreślić, iż na gruncie prawa międzynarodowego stworzenie koncepcji zrównoważonego rozwoju miało przede wszystkim na celu wprowadzenie przeciwwagi dla koncepcji wzrostu gospodarczego ${ }^{292}$ i sformułowanie katalogu norm nadrzędnych, które umożliwiłyby zaspokojenie aspiracji rozwojowych obecnych pokoleń w taki sposób, aby zapewnić również odpowiedni standard rozwoju przyszłym generacjom, a który jest możliwy jedynie przy zachowaniu odpowiednich standardów ochrony środowiska. ${ }^{293} \mathrm{~W}$ dokumentach będących rezultatem Szczytu Ziemi w Rio jasno określony został kierunek działań na najbliższe dekady. Wskazano w nich, iż jednym z fundamentów zrównoważonego rozwoju jest intensywne i świadome zaangażowanie społeczeństwa $\mathrm{w}$ ochronę środowiska. Twórcy powoływanych dokumentów traktują zrównoważony rozwój przede wszystkim w kategoriach globalnych, jednocześnie podkreślając odpowiedzialność państw za rozwój struktur demokratycznych na ich terytorium, a także za znaczenie tychże struktur oraz sposób wzmocnienia ich roli w ochronie środowiska. Jako grupy społeczne, które należały ówcześnie do dyskryminowanych, wskazano m.in. ludność tubylczą, rolników czy struktury i organizacje samorządowe. ${ }^{294}$

Ustrojodawca polski, mocą normy art. 5 Konstytucji, nadał zasadzie zrównoważonego rozwoju rangę zasady konstytucyjnej. W treści tego artykułu wskazano, że Rzeczpospolita Polska, m.in. zapewnia ochronę środowiska, kierując się zasadą zrównoważonego rozwoju. Natomiast w art. 3 pkt 50 ustawy Prawo ochrony środowiska ${ }^{295}$ ustawodawca zawarł definicję legalną zrównoważonego rozwoju. Traktuje on ten rozwój jako rozwój społeczno-gospodarczy, w którym następuje proces integrowania działań o charakterze politycznym, gospodarczym i społecznym, przy jednoczesnym zachowaniu równowagi przyrodniczej, jak również trwałości podstawowych procesów przyrodniczych. Ma to na celu zagwarantowanie możliwości zaspokajania podstawowych potrzeb poszczególnych społeczności lub obywateli zarówno współczesnego pokolenia, jak i przyszłych pokoleń.

Obecnie istniejący w Polsce stan cechuje istnienie dobrze rozwiniętych i umocowanych prawnie struktur demokratycznych, a także funkcjonowanie dobrze rozwiniętych organizacji samorządowych. Zatem należy oczekiwać, że powinny one spełniać istotną rolę $\mathrm{w}$ realizacji ochrony środowiska wykonywanej zgodnie $\mathrm{z}$ zasadą zrównoważonego rozwoju. Ich zadania polegają przede wszystkim na stymulowaniu aktywności poszczególnych grup społecznych w działaniach na rzecz ochrony środowiska, jak również na podnoszeniu poziomu edukacji obywateli w za-

S. Kozłowski, Ekorozwój. Wyzwanie XXI wieku, Warszawa 2002, s. 113.

M. Micińska, Udział społeczeństwa w ochronie środowiska, Toruń 2011, s. 34.

Strategia Zrównoważonego Rozwoju Polski do roku 2025, Ministerstwo Środowiska, Warszawa 1999, s. 3. Patrz również: „Our Common Future” - Nasza Wspólna Przyszłość, Warszawa 1991, s. 67, 71; Our Common Future, The World Commision on Environment and Development, Oxford-New York 1987, s. 6.

M. Micińska, op. cit., s. 34 .

Dz.U. z 2001 r. Nr 62, poz. 627 z późn. zm. 
kresie dbałości o stan środowiska. Niewątpliwym walorem funkcjonowania samorządów terytorialnych jest to, iż z uwagi na to, że są one stosunkowo blisko obywatela, mogą przygotować jednostkę do aktywnych, niewymuszonych działań. Należy przyjąć, że struktury samorządowe kształtują zdolność do podejmowania decyzji o skali lokalnej, umożliwiają obywatelom zarządzanie ich realizacją i kształtują postawy obywatelskie poprzez konieczność ponoszenia odpowiedzialności za decyzje podejmowane $\mathrm{w}$ imieniu innych i $\mathrm{w}$ ich interesie. ${ }^{296}$

Samorządy terytorialne zostały wyposażone w wiele narzędzi prawnych, które pozwalają im aktywnie działać na rzecz ochrony środowiska. Aktywność ta przejawia się m.in. w tworzeniu strategii rozwoju, planowaniu zagospodarowania przestrzennego, wydawaniu decyzji lokalizacyjnych oraz pozwoleń na korzystanie z zasobów środowiska. ${ }^{297}$ Ponadto do zadań samorządów należy edukacja, ochrona zdrowia na swoim terenie czy promocja kultury i rekreacji. W przypadku powiatów zadania te określa przede wszystkim art. 4 ust. 1 ustawy o samorządzie powiatowym. ${ }^{298}$ Umożliwia to samorządom zharmonizowanie procesów rozwoju polityki gospodarczej i infrastrukturalnej z rozwojem społecznym i ekologicznym, a tym samym urzeczywistnianie zrównoważonego rozwoju. ${ }^{299}$

Ochrona środowiska realizowana w zgodzie ze zrównoważonym rozwojem powinna odgrywać znaczącą rolę we współpracy międzynarodowej podmiotów lokalnych, w tym na poziomie transgranicznym. Wynika to ze specyfiki procesów środowiskowych oraz z postępującej globalizacji zjawisk społecznych i ekonomicznych. Zgodnie z dwudziestą piątą zasadą zrównoważonego rozwoju, zawartą w Deklaracji z Rio w sprawie środowiska i rozwoju: „Pokój, rozwój i ochrona środowiska sq wspótzależne i niepodzielne". Oznacza to, że środowisko, które tworzy m.in. powierzchnia ziemi, kopaliny, wody, powietrze czy klimat (art. 3 pkt. 39 ustawy Prawo ochrony środowiska), już ze swej natury nie może być ściśle rozgraniczone pomiędzy poszczególnymi państwami. Jest to szczególnie dostrzegalne w momencie jego degradacji, kiedy zanieczyszczenie czy zniszczenie jednego z komponentów środowiska może wpływać i nierzadko wpływa na pozostałe elementy środowiskowe. Z punktu widzenia Rzeczpospolitej Polskiej takie czynniki, jak kryzys w krajach sąsiadujących, klęska ekologiczna czy zachwiania na rynkach mogą powodować zakłócenie zrównoważonego rozwoju. Niepodzielność środowiska szczególnie widoczna jest na tych terenach, gdzie występują zintegrowane ekosystemy, a obszary te znajdują się na terytorium przynajmniej dwóch państw. W obliczu istniejących zagrożeń konieczna stała się więc współpraca samorządów o charakterze międzynarodowym.

296 Strategia Zrównoważonego Rozwoju Polski..., op. cit., s.19.

297 B. Wierzbowski, B. Rakoczy, Prawo ochrony środowiska. Zagadnienia podstawowe, Warszawa 2010, s. 123-126.

298 Dz.U. z 2001 r. Nr 142, poz. 1592 z późn. zm.

299 Strategia Zrównoważonego Rozwoju Polski..., op. cit., s.19. 


\section{Podstawy prawne współpracy międzynarodowej polskiego samorządu terytorialnego szczebla powiatowego na rzecz ochrony środowiska realizowanej w zgodzie ze zrównoważonym rozwojem}

W celu umożliwienia podmiotom lokalnym współpracy z podmiotami zagranicznymi należało stworzyć formalno-prawne podstawy do tego typu działań. Inicjatywy w tej dziedzinie podjęły się, jako pierwsze, Rada Europy oraz Stowarzyszenie Europejskich Regionów Granicznych. To właśnie pod przewodnictwem Rady Europy stworzono dokumenty, które wprowadziły ujednolicone standardy odnoszące się do najważniejszych reguł współpracy międzynarodowej jednostek regionalnych i które zostaną scharakteryzowane w niniejszym artykule. ${ }^{300}$ Głównymi formami kooperacji pomiędzy podmiotami lokalnymi są: współpraca o charakterze transgranicznym oraz współpraca w ramach euroregionów. Są one istotne między innymi z uwagi na wspomnianą już okoliczność bycia przez Polskę ,wschodnią ścianą" Unii Europejskiej. W związku z tym faktem współdziałanie z regionami państw wschodnioeuropejskich ma szczególny wymiar. Konieczny stał się rozwój współpracy przygranicznej, rozbudowa infrastruktury granicznej, służącej ochronie środowiska, jak również przekazanie polskich doświadczeń, m.in. w dziedzinie ochrony środowiska regionom wschodnich sąsiadów Polski. Współpraca na terenach granicznych stała się niejako gwarancją zapobiegania wykluczeniu czy odsunięciu na margines wschodnich województw Polski. ${ }^{301} \mathrm{~W}$ sposób generalny należy stwierdzić, iż współpraca transgraniczna czy współpraca w ramach euroregionów jest bardzo ważna również ze względu na realizację ochrony środowiska w zgodzie ze zrównoważonym rozwojem. W wyniku współpracy tworzy się sieć powiązań i zależności w zakresie aspektów społecznych, ekologicznych i ekonomicznych. Zrównoważony rozwój odnosił się do trwałości ekologicznej oznaczającej zrównoważone, umiarkowanie wykorzystanie zasobów, rozwoju ekonomicznego uwzględniającego zintegrowanie ochrony środowiska i rozwoju oraz sprawiedliwości społecznej między- i wewnątrzpokoleniowej. ${ }^{302}$

Pierwszym ważnym aktem prawnym, który odnosił się bezpośrednio do współpracy transgranicznej była Europejska Konwencja Ramowa o Transgranicznej Współpracy pomiędzy Władzami i Wspólnotami Terytorialnymi, zwana Konwen-

300 W. Jastrzębska, Rola euroregionów i współpracy transgranicznej w procesie integracji europejskiej, [w:] Spójność społeczno-ekonomiczna a modernizacja regionów transgranicznych, pod. red. M.G. Woźniak, Rzeszów 2008, s. 98.

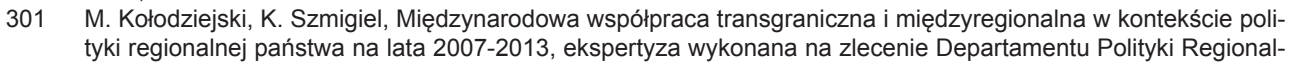
nej w MGiP, s. 4.

302 Definicja zrównoważonego rozwoju zawarta w raporcie „Nasza Wspólna Przyszłość” (raport Brundtland) z 1987 r., cyt za: Ewa-Mazur Wierzbicka, Miejsce zrównoważonego rozwoju w polskiej i unijnej polityce ekologicznej na początku XXI wieku, [w:] Nierówności społeczne a wzrost gospodarczy. Problemy globalizacji i regionalizacji, Część 1, Rzeszów 2006, s. 318. 
cją Madrycką, podpisana 21 maja 1980 roku. W polskim porządku prawnym zaczęła funkcjonować w 1993 r. Sygnatariusze Konwencji zobowiązali się do uznania współpracy transgranicznej jako dopuszczalnej formy aktywności swoich jednostek terytorialnych, a także do wyposażenia ich w odpowiednie kompetencje umożliwiające nawiązanie tej współpracy. W treści Konwencji Madryckiej ustanowiono także zasadę pierwszeństwa prawa wewnętrznego w stosunku do umów i porozumień szczebla lokalnego i regionalnego zawieranych między partnerami współpracy. Postanowieniami Konwencji wprowadzono również pojęcie współpracy transgranicznej do języka prawnego. Zgodnie z brzmieniem Konwencji poprzez współpracę transgraniczną należy rozumieć każde podejmowane wspólnie działanie, którego celem jest umocnienie i dalszy rozwój sąsiedzkich kontaktów między wspólnotami i władzami terytorialnymi dwóch lub większej liczby umawiających się stron, a także zawarcie porozumień i przyjęcie uzgodnień koniecznych do realizacji takich zamierzeń. W powoływanej Konwencji wskazano także, iż ramy tej współpracy stanowią właściwości wspólnot i władz terytorialnych w sposób określony przez prawo wewnętrzne. ${ }^{303}$

Kolejnym ważnym dokumentem międzynarodowym jest Europejska Karta Samorządu Terytorialnego. Sporządzona w 1985 roku, w Polsce weszła w życie w roku 1994. W treści Karty zawarto dość szczegółowo określone postanowienia dotyczące istoty i kompetencji samorządów lokalnych. W przepisach art. 10 ust. 2 i 3 Karty określone zostało prawo społeczności lokalnych do zrzeszania się w międzynarodowe związki i porozumienia współpracy transgranicznej w granicach określonych prawem. Warto w tym miejscu wspomnieć również o Europejskiej Karcie Regionów Granicznych i Transgranicznych. Należy ona do kategorii soft law - stanowi deklarację współpracy. Poruszone zostały w niej najistotniejsze zagadnienia dotyczące europejskiej współpracy transgranicznej i przygranicznej. Karta została opracowana przez Stowarzyszenie Europejskich Regionów Granicznych w 1995 r. ${ }^{304}$ Odzwierciedleniem norm nadrzędnych określonych w prawie międzynarodowym jest art. 172 Konstytucji RP, który ustanawia prawo jednostek samorządu terytorialnego do zrzeszania się, przystępowania do międzynarodowych zrzeszeń społeczności lokalnych i regionalnych oraz współpracy ze społecznościami lokalnymi i regionalnymi innych państw. $Z$ kolei zasady współpracy transgranicznej określone zostały w ustawie z dnia 15 września 2000 roku o zasadach przystępowania jednostek samorządu do międzynarodowych zrzeszeń społeczności lokalnych i regionalnych. ${ }^{305} \mathrm{~W}$ przepisie art. 2 tej ustawy określono, iż jednostki samorządu terytorialnego, przystępując do międzynarodowych zrzeszeń, muszą działać zgodnie z polskim prawem wewnętrznym, polityką zagraniczną państwa oraz jego międzynarodowymi zobo-

303 W. Jastrzębska, Rola euroregionów..., op. cit., s. 99.

304 E. Grzyb, Formy współpracy międzynarodowej jednostek samorządu terytorialnego na przykładzie miasta Chełm, Warszawa 2010, s. 7.

305 Dz.U. z 2000 r. Nr 91, poz. 1009 z późn. zm. 
wiązaniami. W przypadku niespełnienia tego warunku minister właściwy do spraw zagranicznych może cofnąć zgodę na przystąpienie do zrzeszenia międzynarodowego (art. 10 ust. 2 ustawy). Powtórzenie tych wymogów można znaleźć w ustawach o samorządzie gminnym, powiatowym i wojewódzkim.

Istniejąca na przestrzeni ostatnich 30 lat praktyka pozwala na stwierdzenie, że nie zawsze prawo wewnętrzne poszczególnych państw pozwala na zrealizowanie zamierzonych działań. Jest to wynikiem tego, że uregulowania wewnątrzkrajowe, w których zawarto uprawnienia do podejmowania przez samorządy działań w zakresie międzynarodowego obrotu publiczno-prawnego, nie zawsze mogą zostać uznane za wystarczające w tym obszarze.

Należy stwierdzić, iż polski system prawny regulujący udział samorządu terytorialnego we współpracy międzynarodowej w porównaniu do regulacji międzynarodowych jest niekompletny i stwarza bariery we wzajemnej kooperacji. ${ }^{306} \mathrm{~W}$ tym miejscu warto posłużyć się przykładem regulacji zawartych w ustawie o samorządzie powiatowym, gdzie w art. 12 pkt. 9a ustawodawca w sposób ogólny określa, iż do właściwości rady powiatu należy podejmowanie uchwał w sprawach dotyczących współpracy ze społecznościami lokalnymi innych państw, a także przystępowania do międzynarodowych zrzeszeń społeczności lokalnych. W przepisach ustawy o samorządzie powiatowym uregulowano również sposób przekazywania kompetencji decyzyjnych oraz sposób zawiązywania powiatowych związków, stowarzyszeń i porozumień. Współpraca między jednostkami samorządu terytorialnego może następować nie tylko na płaszczyźnie horyzontalnej, ale i między jednostkami różnego stopnia, tj. między powiatami i gminami. To właśnie stowarzyszenia powiatów i gmin stały się podstawą euroregionów. W tym kontekście powstał problem przystępowania do stowarzyszeń utworzonych przez jednostki samorządu terytorialnego, działające na podstawie prawa polskiego, jednostek samorządu terytorialnego innych państw. Należy przyjąć, że taka możliwość wynika z brzmienia art. 22 i art. 4 ustawy Prawo o stowarzyszeniach. ${ }^{307}$ Zgodnie z nimi zagraniczne jednostki samorządu terytorialnego, jako że są osobami prawnymi, mogą bez przeszkód przystąpić do związku stowarzyszeń. Uznaje się jednak, że w warunkach polskich podmioty te mogą być tylko członkami wspierającymi. ${ }^{308}$

Główną formą współpracy pomiędzy podmiotami lokalnymi są wielostronne umowy międzynarodowe lub bilateralne porozumienia między państwami. Polska podpisała takie umowy ze wszystkimi państwami ościennymi. Do najważniejszych elementów tychże umów należą: obowiązek informowania przez władze centralne władz regionalnych i lokalnych o możliwości podjęcia takiej współpracy, obowiązek strony do usunięcia wszelkich przeszkód prawnych mogących ograniczać współ-

306 E. Grzyb, op. cit., s. 4.

307 Dz.U. z 1989 r. Nr 20, poz. 104 z późn. zm.

308 E. Grzyb, op. cit., s. 13. 
działanie, określenie zakresu przedmiotowego podejmowanej współpracy, wskazanie możliwości powołania odpowiednich komisji międzyrządowych lub innych organów koordynujących, ewentualnie ustanowienie klauzul wyłączających dane terytorium z tej współpracy. Z kolei w odniesieniu do euroregionów ich organizację regulują statuty, porozumienia o utworzeniu danego euroregionu oraz regulaminy ich organów. ${ }^{309}$ Ważnym elementem umów jest określenie wymogu zgodności działań z prawem krajowym. Współpraca pomiędzy podmiotami lokalnymi musi być więc zgodna $\mathrm{z}$ prawem wewnętrznym państw, ale także w prawidłowy sposób realizować przyjęte przez dane państwo regulacje aktów międzynarodowych. Wypada zwrócić uwagę na problem różnic, jakie występują pomiędzy jednostkami samorządu terytorialnego zawierającymi porozumienia. Ich uwarunkowania polityczne i gospodarcze sprawiają, że we współpracy może występować zjawisko nierówności potencjałów gospodarczych i finansowych, co wynika m.in. z dysproporcji w dostępie do funduszy i programów regionalnych Unii Europejskiej. Ta asymetria powoduje, iż nie wszystkie działania mogą być podejmowane przez współpracujące państwa równomiernie i na takim samym poziomie, a to tworzy pytanie o sens wspólnych przedsięwzięć. ${ }^{310} \mathrm{~W}$ ramach aktywności podmiotów lokalnych na rzecz ochrony środowiska niespójne i nieharmonijne działania mogą stanowić wyraźną przeszkodę w utrzymaniu odpowiedniego standardu ochrony środowiska, a przy tym zachowaniu unikalności i niezmienności terenów należących do kilku państw. Jak już wspomniano wyżej, środowisko jest swego rodzaju nierozerwalnym zbiorem elementów, pomiędzy którymi zachodzą dynamiczne interakcje, a zaniechanie ochrony jednego z nich może i, nierzadko negatywnie wpływa na pozostałe. Zatem nierównomierna ochrona danego terenu może uniemożliwić osiągnięcie zakładanego przez państwa celu, jakim jest utrzymanie stanu środowiska na odpowiednim poziomie. Przykładem tego typu problemów jest współpraca jednostek samorządu terytorialnego w ramach Euroregionu Pomerania. Stronami umowy są tu zrzeszenia podmiotów lokalnych Polski, Niemiec oraz Szwecji. Zgodnie z umową o utworzeniu euroregionu celem współpracy w Euroregionie Pomerania jest między innymi podejmowanie wspólnych działań na rzecz równomiernego i zrównoważonego rozwoju regionu. Cel ten ma być zrealizowany głównie poprzez utrzymanie oraz poprawę stanu środowiska naturalnego, poprawę gospodarki rolnej i leśnej czy rozwój skoordynowanego transgranicznego planowania przestrzennego. Cześć środków na realizację zadań dofinansowywana jest z funduszu Unii Europejskiej, który umożliwił realizowanie projektów właśnie z zakresu ochrony środowiska, tj. budowanie i utrzymywanie oczyszczalni ścieków, kanalizacji sanitarnych czy modernizację systemów ogrzewania. $Z$ dotychczasowych doświadczeń we współpracy tego euroregionu wynikają jednak problemy w postaci nierówności o charakterze finan-

309 Tryb dostępu: http://lukdan.vxm.pl/karpacki/podstawy_prawne, dnia 14.12.2012 r.

310 Tryb dostępu: http://biurose.sejm.gov.pl, dnia 14.12.2012 r. 
sowym, społecznym czy prawnym. Ponadto uwidacznia się różny poziom zaangażowania we współpracę wynikający m.in. z bariery językowej, a także braku doświadczeń w instytucjonalizacji współpracy. ${ }^{311}$ Zauważalne są również bariery polegające na skomplikowanych procedurach realizacji i rozliczania projektów unijnych oraz istnieniu zbyt wielu instytucji pośredniczących. Co więcej, w ramach niektórych projektów nie ma możliwości uzyskania zaliczek na ich realizację, co już na starcie dyskwalifikuje niektóre regiony. Okres oczekiwania na zwrot poniesionych kosztów realizacji projektów jest natomiast bardzo długi. Istnieje również problem występowania niejednolitych procedur rozliczania projektów w poszczególnych częściach krajów. Na gruncie prawnym kolejną przeszkodą, obok niedostatecznych regulacji, są różnice $\mathrm{w}$ rozwiązaniach prawnych w państwach będących stronami umów czy też różnice w zakresach kompetencji organów państwowych i samorządowych. ${ }^{312}$

Dostrzegając potrzebę zmian w istniejącym stanie prawnym, należy podkreślić rolę Europejskiej Karty Samorządu Regionalnego, której celem jest kontynuacja idei zawartej w Europejskiej Karcie Samorządu Lokalnego. Europejską Kartę Samorządu Regionalnego (EKSR) przyjęto 5 czerwca 1997 r., jednak do dziś nie stanowi ona aktu prawa międzynarodowego, ponieważ nie uzyskała koniecznego poparcia ze strony państw członkowskich Rady Europy ani też aprobaty jej organu stanowiącego, którym jest Komitet Ministrów. Jej postanowienia wyrażają koncepcję miejsca i roli ustrojowej regionów we współczesnej Europie. Postanowienia Karty odzwierciedlają całkowitą zmianę myślenia o podmiotach samorządowych współpracujących na szczeblu międzynarodowym. Regiony są tu traktowane jako szczebel administracji publicznej między rządem a samorządem lokalnym, wyposażony w odrębną od państwa i jednostek lokalnych osobowość prawną oraz jako organ stanowiący, wyłaniany w powszechnych wyborach, który posiadałby własne organy wykonawcze i aparat administracyjny, budżet z własnymi źródłami dochodów, a także znaczny zakres zadań i kompetencji. Dzięki temu regiony uzyskałyby większy wpływ na ustalenia ich dotyczące podejmowane na szczeblu międzynarodowym i ponadnarodowym. Europejska Karta Samorządu Regionalnego nadal znajduje się na etapie projektu, ale niezmiennie budzi kontrowersje, gdyż przewiduje się w niej istnienie regionów posiadających przymioty kojarzone zazwyczaj z państwem. ${ }^{313}$ Przyjęcie tego aktu z pewnością miałoby istotne znaczenie w obszarze samorządności regionalnej. Być może zniwelowałoby część istniejących obecnie barier, a cechy samodzielności przypisane poszczególnym regionom pozwoliłyby im na realne zwalczanie problemów istniejących na danych terenach.

311 Ibidem.

312 Tryb dostępu: http://www.stat.gov.pl, dnia 14.12.2012 r.

313 E. Grzyb, op. cit. s. 9. 


\section{Uwagi końcowe}

Nie może podlegać dyskusji, że współpraca międzynarodowa na poziome powiatów, które co do zasady realizują zadania o charakterze lokalnym, jest zjawiskiem wymagającym precyzyjnej regulacji prawnej. Prawne ukonstytuowanie działalności jednostek samorządu terytorialnego tak, aby ich aktywność przynosiła zamierzone efekty oraz harmonizowała uregulowania prawne szczebla międzynarodowego i szczebla krajowego poszczególnych państw, jest zadaniem trudnym. Wymaga to funkcjonowania takich norm, które umożliwią godzenie wartości wyrażonych w prawie międzynarodowym i prawie poszczególnych państw. Dodatkową trudność, w normatywnym uregulowaniu tej sfery aktywności podmiotów prawa, powoduje częsta rozbieżność interesów poszczególnych aktorów sceny międzynarodowej z jednej strony i jednostek działających na szczeblu lokalnym poszczególnych państw z drugiej strony.

W zakresie realizacji ochrony środowiska ma to szczególne znaczenie. Błędne a nawet jedynie dysharmonijne działania władz lokalnych (w tym szczebla powiatowego), prowadzone na przestrzeni wykraczającej poza terytorium jednego państwa, mogą powodować negatywne, nieodwracalne skutki w elementach przyrodniczych. Jednocześnie ochrona niektórych komponentów środowiska, takich jak np. klimat czy wody morskie, może być skutecznie prowadzona tylko w przypadku koordynacji działań na poziomie wykraczającym poza działalność pojedynczego państwa.

Realizacja ochrony środowiska i prowadzenie zrównoważonego rozwoju winny być traktowane we współczesnym świecie jak procesy nierozerwalnie związane ze sobą, których rozdzielenie nie powinno i nie może mieć miejsca. Zatem istnienie barier prawnych we współpracy międzynarodowej (w tym tej prowadzonej na poziomie powiatów), w zakresie ochrony środowiska winno być traktowane jako istnienie barier we współpracy na rzecz zrównoważonego rozwoju. Jednocześnie nie można tracić z pola widzenia oczywistej zależności, wyrażającej się w tym, że istnienie tych barier zazwyczaj prowadzi do ograniczenia aktywności podmiotów prowadzących współpracę. Tę zaś okoliczność należy traktować jako szczególnie niepożądaną, zarówno w zakresie działań na rzecz ochrony środowiska, jak i zrównoważonego rozwoju. 


\section{INTERNATIONAL COOPERATION OF POLISH LOCAL GOVERNMENT AT THE COUNTY LEVEL IN THE FIELD OF ENVIRONMENTAL PROTECTION IMPLEMENTED IN ACCORD WITH SUSTAINABLE DEVELOPMENT}

The article references the international cooperation of local governments, focusing primarily on cooperation counties, in the context of their implementation of the principles of sustainable development. The article characterises sustainable development within the meaning of international law and Polish law, in regard to the implementation of environmental protection. The authors also take into consideration to what extent and how effectively counties, through international cooperation, perform tasks in the field of environmental protection whilst at the same time realizing the principles of sustainable development, and what barriers exist on that base. The authors therefore indicate legal and factual obstacles to international cooperation counties. The basis for discussion is primarily national and international legislation, and the authors, at the outset, determine the legal basis for international cooperation by Polish local government at county level for the protection of the environment and indicate the basic forms of this cooperation.

Keywords:

County government, sustainable development, international cooperation, environmental protection, euroregion, cross-border cooperation 